\title{
High-resolution Data Based Groundwater Recharge Estimations of Aynalem Well Field
}

\section{Abdelwassie Hussien ${ }^{*}$, Tesfamichael G. Yohannes', Miruts Hagos ${ }^{1}$, Gebremedhin Berhane $^{1}$, Kassa Amare ${ }^{1}$ and Gebremedhin Berhe Zenebe ${ }^{2}$}

\author{
${ }^{1}$ School of Earth Sciences, College of Natural and Computational Sciences, P.O. Box 231, Mekelle \\ University, Ethiopia (*abdelwassiehb@gmail.com). \\ ${ }^{2}$ Tigray Agricultural Research Institute, Mekelle Soil Research center P.O. Box 1070, Mekelle, \\ Ethiopia.
}

\begin{abstract}
Due to the ever-increasing demand for water in Aynalem catchment and its surrounding, there has been an increased pressure on the Aynalem well field putting the sustainability of water supply from the aquifer under continuous threat. Thus, it is vital to understand the water balance of the catchment to ensure sustainable utilization of the groundwater resource. This in turn requires proper quantification of the components of water balance among which recharge estimation is the most important. This paper estimates the groundwater recharge of the Aynalem catchment using high-resolution hydro-meteorological data. Daily precipitation and temperature measurement data for years 2001-2018; groundwater level fluctuation records collected at every 30 minutes; and soil and land use maps were used to make recharge estimations. In the groundwater level fluctuation, three boreholes were monitored, but only two were utilized for the analysis because the third was under operation and does not represent the natural hydrologic condition. Thornthwaite soil moisture balance and groundwater level fluctuation methods were applied to determine the groundwater recharge of the Aynalem catchment. Accordingly, the annual rate of groundwater recharge estimated based on the soil-water balance ranges between $7 \mathrm{~mm} /$ year and $138.5 \mathrm{~mm} / \mathrm{year}$ with the weighted average value of $89.04 \mathrm{~mm} / \mathrm{year}$. The weighted average value is considered to represent the catchment value because the diverse soil and land use/cover types respond differently to allow the precipitation to recharge the groundwater. On the other hand, the groundwater recharge estimated using the groundwater level fluctuation method showed yearly groundwater recharge of 91 to $93 \mathrm{~mm} /$ year. The similarity in the groundwater recharge result obtained from both the methods strengthens the acceptability of the estimate. It also points out that the previously reported estimate is much lower (36 to $66 \mathrm{~mm} / \mathrm{year}$ ).
\end{abstract}

Keywords: Groundwater, Recharge estimation, Aynalem well field, Tigray, Ethiopia.

\section{INTRODUCTION}

According to the Sustainable Development Goals of the UN (SDG, 2015), everyone on earth should have access to safe, clean, and affordable drinking water by 2030. Meanwhile, an increase in population in many towns, climate change and its variability, expansion of irrigated agriculture, and change in the living standards due to economic development also denote an increase in the demand for water. Groundwater is the main source of water supply in many arid and semi-arid 
regions and actions taken to solve the demands have led to excessive groundwater abstraction, which in turn caused over-exploitation or persistent groundwater depletion (Yoshihide et al., 2010). This necessitated the need for proper groundwater management. Hence, estimation of groundwater recharge is of critical importance for safe and efficient management of groundwater resources (Misstear, 2006). Recharge is a function of many parameters such as level of soil development, climatic conditions, and land use/land cover. Therefore, selecting the best techniques of recharge estimation mechanisms is of paramount importance.

Recharge has been estimated using a variety of techniques (Sophocleous, 1991; Scanlon et al., 2006; Scanlon et al., 2002; Lerner et al., 1990; Hendrickx, 1997; Zhang, 2001; Kinzelbach, 2002) including physical, chemical and modeling techniques. Sophocleous (1991) illustrated the physical methods as: (1) hydrometeorological and soil-crop data processing to determine the soil water balance; (2) hydrologic data interpretation, including analysis of water table fluctuations, and differential streamflow analysis; and (3) soil physics measurements (hydraulic or Darcian approach), including estimation of water fluxes beneath the root zone using unsaturated hydraulic conductivity functions and water potential gradients. The chemical methods consist of chemical and isotopic analysis of pore fluids from the saturated and unsaturated zones. Grismer et al. (2000) focused on field methods for the evaluation of aquifer recharge in arid and semi-arid regions. Recharge estimations have also been made by multiplying the magnitude of water-level fluctuations in wells, to the specific yield of the aquifer model (Avery et al., 1999). Analytical methods and estimation of groundwater recharge from water storage structures (Xiuyu Liang and You-Kuan Zhang, 2012; Sharda et al., 2006) and combined estimation of specific yield and natural recharge in a semi-arid groundwater basin with irrigated agriculture (Maréchal et al., 2006) were other techniques for estimating annual groundwater recharge.

The Aynalem wellfield has been the main water supply source for Mekelle town and the surrounding villages for over 30 years. The number and depth of the wells drilled in the past have been increased due to increased demand for water supply attributable to an increasing population and enhanced socio-economic activities and this was coupled with the declining water table. The observation so far is that the groundwater is going deeper and the shallow wells are being dried up. Thus, the sustainability of the water supply from the wellfield has been increasingly 
threatened. Moreover, to have good management it is compulsory to know how much we have, how much we are taking, and how much is being recharged. Hence, knowing the recharge amount accurately is an important aspect of groundwater management.

A number of hydrogeological investigations focusing on recharge estimation have been carried out in the area by different researchers. For example, using Thornthwaite and Mather water balance method (Hussien, 2000; Yehdego, 2003; Zeray, 2007; Samuel, 2017) using the Chloride mass balance method (Vanum and Gebrerufael, 2012, Hailu, 2008; Gebru et al., 2018), using the WATBAL model (Gebrehawaria, 2009) and by applying WetSpass Model (Tesfamichael et al., 2013; Kibrewossen, 2011). The scope of some of these research works covered the whole Geba basin and both Aynalem-Elala catchments. Hence, the results are not specific to the Aynalem well field. The values obtained from these research works reveal that the annual recharge from direct precipitation ranges from $36 \mathrm{~mm}$ to $66 \mathrm{~mm}$ per year for the Aynalem catchment. The possible source of this variation could be attributed to the use of mean monthly meteorological data to estimate the components of the hydrologic cycle and soil and land use maps prepared from limited samples as input files.

The main objectives of this work are therefore, to present estimates of groundwater recharge by means of soil-water balance (based on daily meteorological data, detailed soil and land use/cover maps) and groundwater-level fluctuation measurements (collected at an interval of 30 minutes for a period of one hydrologic year).

\subsection{Description of the Study Area}

Aynalem is a small town located at the southeast outskirt of the Mekelle city, which is dominantly a rural village, and the study area, Aynalem catchment is named after this village. Geographically, the study area is bounded by longitudes of $39^{\circ} 27^{\prime} 30^{\prime \prime}$ and $39^{\circ} 38^{\prime} 30^{\prime \prime}$ East and latitudes of $12^{\circ} 24^{\prime} 30^{\prime \prime}$ and $12^{\circ} 28^{\prime} 33^{\prime \prime}$ North. It is accessible through the asphalt road connecting Mekelle and Addis Ababa and a network of dry weather roads traversing the study area (Fig 1).

The Aynalem well field has a semi-arid climatic condition with mean annual precipitation of 549 $\mathrm{mm} /$ year and mean maximum and minimum temperature of $25.6^{\circ} \mathrm{C}$ and $12.1^{\circ} \mathrm{C}$, respectively. The Aynalem catchment has a dendritic drainage pattern with Aynalem stream being the main river draining the catchment starting in the northeastern part and leaving at the southwestern part of the 
study area. The study area is characterized to be a relatively flat land with few hills of dolerite sills and uplifted limestone.

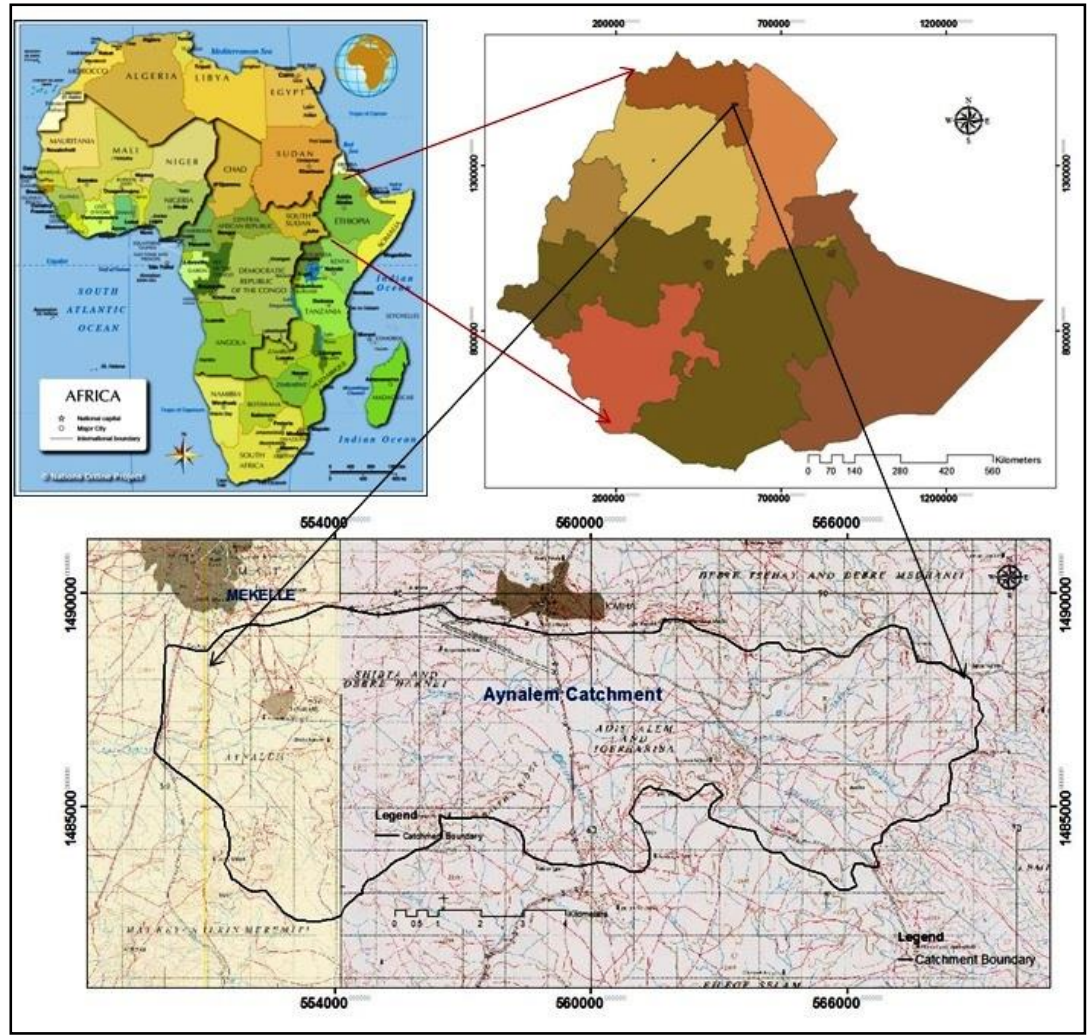

Figure 1. Location map of the Aynalem catchment area with reference to Ethiopia and Africa.

\section{GEOLOGY OF THE AREA}

The Aynalem catchment is found at the eastern block and upper succession of the Mekelle outlier. The area is covered by three geological units' namely alluvial deposits, dolerite sills, and fossiliferous limestone-marl-shale intercalation units (Fig 2).

Alluvial deposits cover the central part following the mainstream (Aynalem) of the area (Fig 2). This unit is predominantly composed of black-cotton soil derived from the nearby dolerites and carbonate rocks. At places, when there is a transition between the shale and the overlying sandstone, there is a development of fine-grained sand to silt. As observed from the various boreholes, it has a maximum thickness of about 10 meters. 


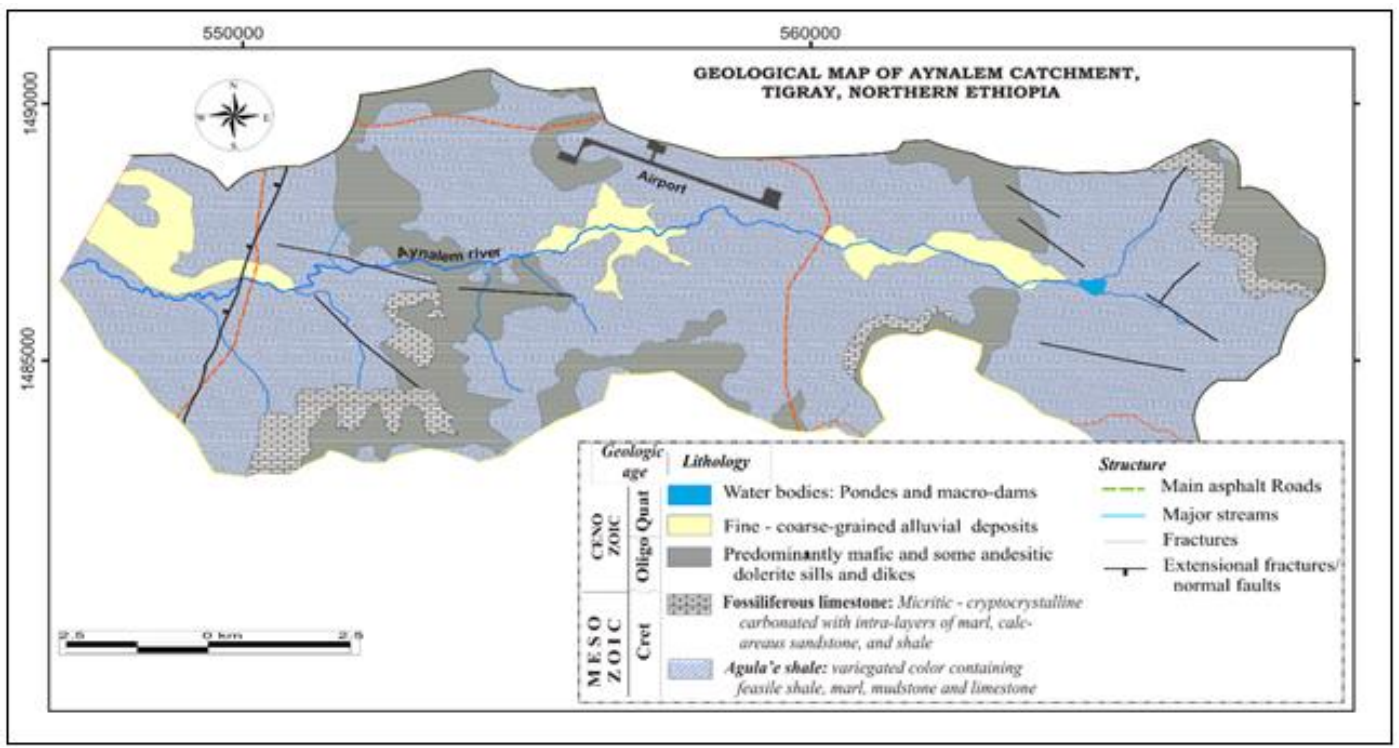

Figure 2. Geological map of Aynalem area.

The presence of dolerite sills and dikes has been reported since 1938 (Arkin et al., 1971; Tesfamichael et al., 2010). However, the nature and extent of the dolerites remained unclear. Except for preliminary geochemical studies and simplified geodynamic aspects, the dolerite architecture was not modeled. Aynalem area, as one block of the dolerite, injected Mekelle outlier; there is no single area that is free from the dolerite interference. The entire Aynalem catchment is injected by dolerite sill but at different depths. Some are exposed on the surface and others are found up to a depth of $200 \mathrm{~m}$ (Fig 3). The Aynalem sill/sills are a southwestern extension of the Endayesus mega-sill that intrudes the lower part of the Agula shale. It is dark brown in color and shows porphyritic texture, laths of plagioclase feldspar phenocrysts in a fine-grained matrix.

Micritic limestone unit underlying dolerite sills is massive, about 20m thick, form part of Antalo Limestone Formation occurs as beds. There are also thin fossiliferous layers of carbonate present between the beds.

Agula shale is the dominant exposure in the catchment, at places intercalated with layers of limestone, marl and mudstones. It forms part of Agula Shale Formation which is dominant in the entire central Mekelle Basin. Mekelle dolerites with variable thickness, maximum of about $120 \mathrm{~m}$ are present as intrusive bodies in shale, limestone and marl (Fig 3). 


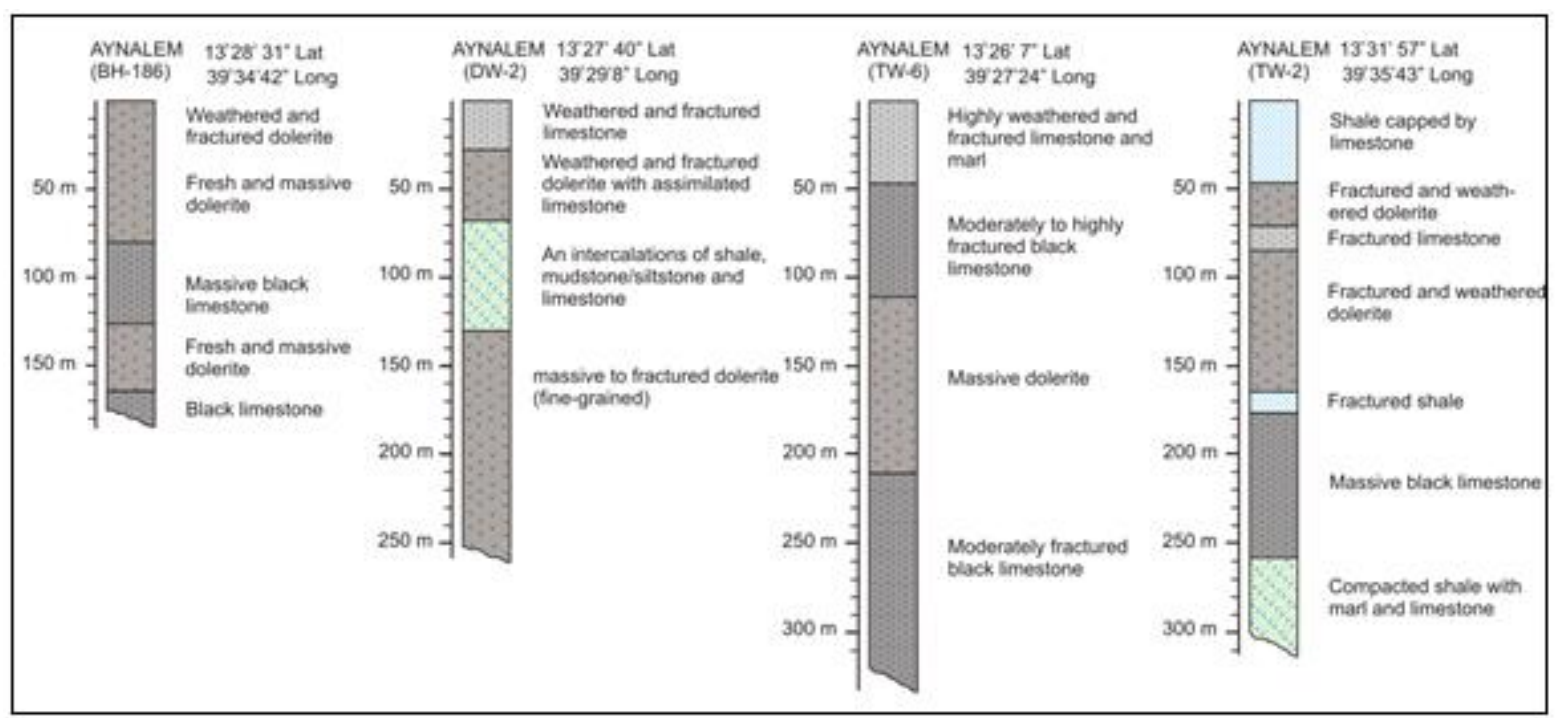

Figure 3. Four deep borehole data showing the vertical profile of Aynalem area (Modified from Water resource Bureau of Tigray).

\section{METHODOLOGY}

The accurate result of groundwater recharge estimation depends on the method applied as well as on the quality of data used. Several groundwater recharge estimation methods have been developed that suit best for different climatic zones and for different degrees of data availability. These methods also deliver different results based on the level of details of the data provided. In this study, Soil Moisture Balance and Groundwater Level Fluctuation methods were applied to determine the groundwater recharge of the Aynalem catchment.

\subsection{Soil-Moisture Balance}

In the soil moisture balance method groundwater recharge and runoff is computed using the Thornthwaite and Mather Water Balance (TMWB) model programmed in an excel sheet (McCabe and Markstrom, 2007). In this model, daily evapotranspiration estimations, Plant Available Water (PAW) for different hydrologic soil groups, defined catchment representative curve number $(\mathrm{CN})$, and daily rainfall measurements were required as inputs and are given below.

\subsubsection{Evapotranspiration}

Potential evapotranspiration is the amount of water that can be evaporated under a sufficient amount of water. However, the availability of the water for evapotranspiration depends not only 
on direct precipitation but also on the water that has been accumulated in the soils during rainy periods. As soils vary greatly in their capacity to store water, understanding their storage capacity is important in defining evapotranspiration. If the demand for water largely exceeds the available water, soil moisture is depleted and plants eventually die (Ritter, 2006). Though there are several methods for estimating evapotranspiration, the ETo calculator version 3.2, issued in 2012, was used to calculate evapotranspiration. The Penman Montheith method calculates the reference crop Evapotranspiration (ETo), using daily data of maximum temperature, minimum temperature, wind speed, relative humidity, and sunshine hours. The maximum crop Evapotranspiration (ETm), when water supply fully meets the water requirements of the crop, is calculated from the reference crop Evapotranspiration (Allen et al., 1998).

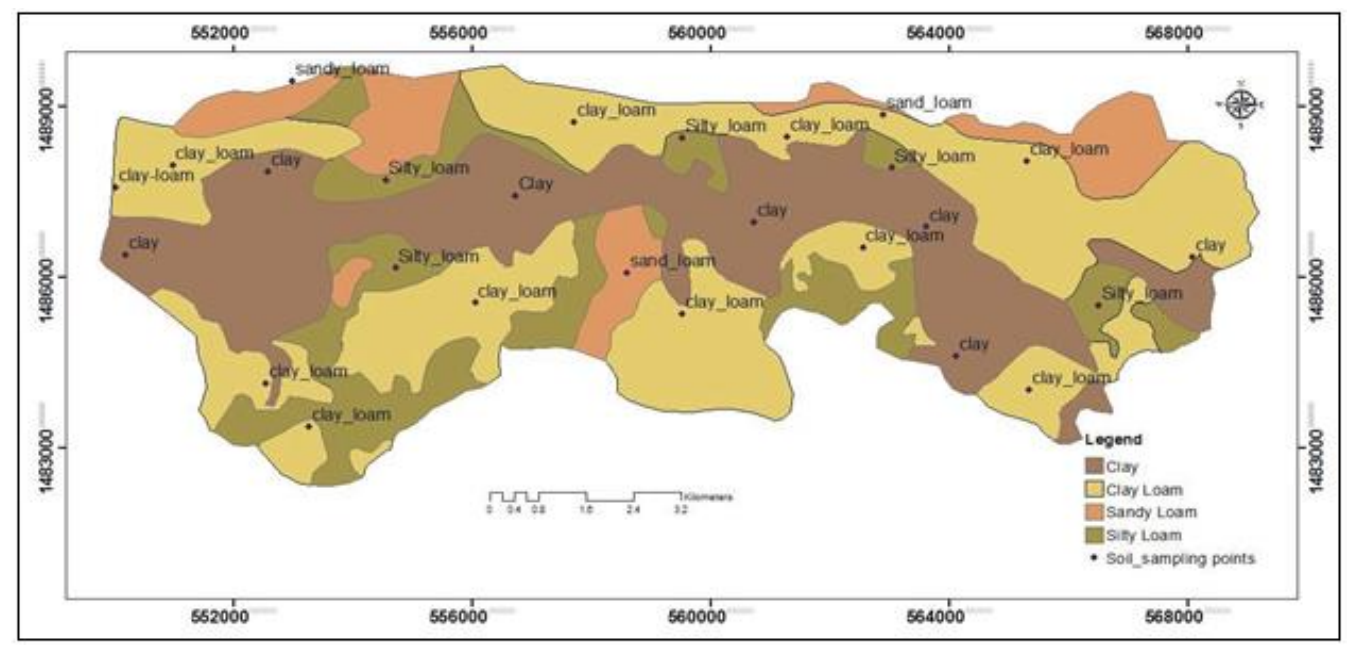

Figure 4. Soil map of Aynalem Catchment.

\subsubsection{Plant Available Water (PAW)}

In order to determine the plant available water (PAW) twenty-six soil samples were collected from representative sites. The sites were selected based on field traverses and satellite image interpretations. The soil samples were analyzed in the geotechnical laboratory of the Tigray Water Resources Bureau. The hydrometer and sieve analysis method of laboratory analysis was employed (Table 1). Results revealed that, based on the USDA soil classification method (Fetter, 2001), the soil types are sandy loam, silt loam, clay loam, and clay (Fig 4). 
Table 1. Laboratory analysis result of soil samples.

\begin{tabular}{|lllllll|}
\hline ID & $\boldsymbol{X}$ & $\boldsymbol{Y}$ & \%Sand & \% Silt & \% Clay & USDA Soil Classification \\
\hline S 1 & 550183 & 1486382 & 19 & 21 & 60 & Clay \\
\hline S 2 & 550014 & 1487568 & 37 & 24 & 39 & clay-loam \\
\hline S 3 & 552533 & 1484117 & 44 & 28 & 28 & clay loam \\
\hline S 4 & 553253 & 1483355 & 40 & 31 & 29 & clay loam \\
\hline S 5 & 550967 & 1487949 & 41 & 30 & 29 & clay loam \\
\hline S 6 & 552575 & 1487843 & 19 & 23 & 58 & Clay \\
\hline S 7 & 552977 & 1489430 & 23 & 55 & 22 & Silty loam \\
\hline S 8 & 554544 & 1487695 & 26 & 51 & 23 & Silty loam \\
\hline S 9 & 556724 & 1487419 & 17 & 27 & 56 & Clay \\
\hline S 10 & 554713 & 1486149 & 26 & 54 & 20 & Silty loam \\
\hline S 11 & 556047 & 1485536 & 39 & 30 & 31 & clay loam \\
\hline S 12 & 558587 & 1486065 & 68 & 16 & 16 & sandy loam \\
\hline S 13 & 559518 & 1485345 & 41 & 29 & 30 & clay loam \\
\hline S 14 & 560725 & 1486954 & 24 & 25 & 51 & Clay \\
\hline S 15 & 559518 & 1488435 & 23 & 56 & 21 & Silty loam \\
\hline S 16 & 557698 & 1488711 & 41 & 31 & 28 & clay loam \\
\hline S 17 & 561275 & 1488457 & 37 & 31 & 32 & clay loam \\
\hline S 18 & 562545 & 1486509 & 40 & 30 & 30 & clay loam \\
\hline S 19 & 563032 & 1487906 & 20 & 59 & 21 & Silty loam \\
\hline S 20 & 562884 & 1488838 & 67 & 15 & 18 & sandy loam \\
\hline S 21 & 563603 & 1486869 & 20 & 26 & 54 & Clay \\
\hline S 22 & 56411 & 1484604 & 19 & 26 & 55 & Clay \\
\hline S 23 & 565297 & 1488033 & 35 & 31 & 34 & clay loam \\
\hline S 24 & 566503 & 1485493 & 18 & 60 & 22 & Silty loam \\
\hline S 25 & 565339 & 1484012 & 41 & 23 & 36 & clay loam \\
\hline S 26 & 568069 & 1486340 & 20 & 28 & 52 & Clay \\
\hline & & & & & & \\
\hline
\end{tabular}

The downward movement of water in to the ground largely depends on the type of soil cover, which in turn is a function of soil texture, compactness and clay content. Thus anchored in the grain size distribution and textural classification, the wilting point, field capacity and saturated hydraulic properties of each soil group were calculated using the "Soil Water Characteristics Hydraulic Properties Calculator developed by Saxton et al. (1986).

Finally, these results were utilized in the determination of the water available in the soils, which is known as plant available water capacity (PAW). PAW is the difference between the upper 
water storage limit of the soil and the lower extraction limit of crop over the rooting depth (Ratliff et al., 1983). After analysis of the soil data, it was found out that the entire study area falls under the Hydrological Soil Groups 'C' and 'D'.

\subsubsection{Curve Number estimation/determination}

The curve number $(\mathrm{CN})$ is an important parameter in running the Thornthwaite and Mather Water Balance (TMWB) model programmed in an excel sheet (McCabe and Markstrom, 2007). Hence, in order to generate a curve number, land use/land cover map was produced (Fig 5). The result of land use/land cover classification of land sat satellite image indicates that different land use/land cover categories were present in the study area. Accordingly, the land use/land cover patterns in the catchment are farmland (55.35\%), bare land (31.34\%), vegetation cover (6.77), and scattered rural settlements (farmsteads) (6.1\%) and water bodies (0.44\%) (Fig 5). The result of image processing was verified against ground control points, which was found to be acceptable with an accuracy level of about $83 \%$. Deforestation has left much of the land with scarce vegetation; the vegetation cover comprises Eucalyptus trees, bushes and shrubs while the major crops in the catchment are wheat, sorghum, teff and barley.

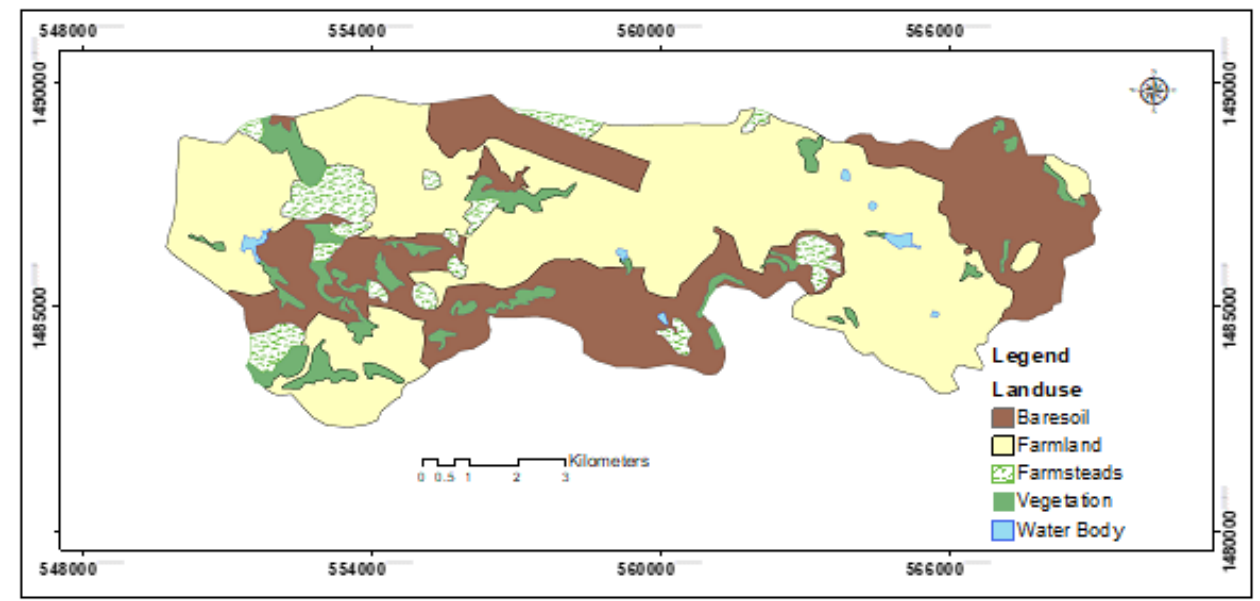

Figure 5. Land use/Land cover map of the study area, processed using both landsat ETM+ and SPOT imageries.

The weighted curve number was generated using land use / land cover map, hydrologic soil group and standard curve number table from the values suggested by USDA, (1972) (Annexure I), defined for antecedent soil moisture condition II (AMCII). Since an area with a particular soil type and land use ascribes a unique $\mathrm{CN}$ value, the catchment was divided into values (C) CNCS, Mekelle University 
of different curve numbers. Then a weighted curve number was evaluated. Thus, the generated weighted Curve Numbers were used for prediction of runoff from the catchment (Table 2).

Table 2. Weighted curve number $(\mathrm{CN})$ of different soil groups in the study area.

\begin{tabular}{|lclllll|}
\hline $\begin{array}{l}\text { Land } \\
\text { use/cover }\end{array}$ & Area $\left(\mathbf{m}^{\mathbf{2}}\right)$ & Proportion & $\begin{array}{l}\text { CNfor C } \\
\text { soil group }\end{array}$ & $\begin{array}{l}\text { CNfor D } \\
\text { soil group }\end{array}$ & $\begin{array}{l}\text { Adjusted } \\
\text { CN for C }\end{array}$ & $\begin{array}{l}\text { Adjusted } \\
\text { CN for D }\end{array}$ \\
\hline Water & 418,987 & 0.004 & 0 & 0 & 0 & 0 \\
\hline Vegetation & $6,401,306$ & 0.068 & 70 & 77 & 4.7 & 5.2 \\
\hline Farmstead & $5,770,569$ & 0.061 & 82 & 86 & 5 & 5.2 \\
\hline Bare soil & $29,636,163$ & 0.313 & 86 & 89 & 26.9 & 27.9 \\
\hline Farmland & $52,345,628$ & 0.553 & 78 & 81 & 43.2 & 44.8 \\
\hline & $94,572,653$ & 1 & & & 80 & 83 \\
\hline
\end{tabular}

At the end, the groundwater recharge and runoff were computed using the Thornthwaite and Mather Water Balance (TMWB) model programmed in an excel sheet (McCabe and Markstrom, 2007), by using daily evapotranspiration estimations, Plant Available Water (PAW) of the different hydrologic soil groups, weighted curve number $(\mathrm{CN})$ and daily rainfall measurements (Annexure II).

\subsection{Water Table Fluctuations}

This method of groundwater recharge estimation measures the effect of recharge at the water table defined as a rise in the water level, which in turn provides estimates that correspond to the amount of percolated water i.e. the downward movement of water to join the saturated zone. Water-table fluctuation (WTF) method have been used as one of the appropriate methods to estimate groundwater recharge and discharge conditions in many parts of the world especially in arid and semi-arid regions (Rasmussen and Andreasen, 1959; Sophocleous, 1991; Christian et al., 2000; Marcelo et al., 2013; Nimmo et al., 2015. However, in order to estimate the recharge from these water-level fluctuations an appropriate value of specific yield (SY) should be known. The specific yield represents the void space that will allow movement of water to wells and hence the specific yield of the rock or soil materials comprising the zone of water-table fluctuation must be determined in order to estimate the available water supply represented by the rise in the water table during a period of recharge. In this study, the SY values from (Johnson, 1967) were adopted and 
the values were adjusted based on the proportion of the local soil properties. Since four types of soils characterize the area, a weighted SY was utilized in calculating the recharge of the catchment (Table 4).

The groundwater level fluctuation data of 2017 collected using DIVER water level loggers, from both pre and post-rainy season (Covering one hydrologic year) and corresponding rainfall data of the study period were simultaneously collected. The water-level rise $(\Delta \mathrm{h})$ was set equal to the difference between the peak of the rise and lowest point of the extrapolated antecedent recession curve of the well hydrograph at the time of the peak. Then the recharge was computed by multiplying the rise by the specific yield of the aquifer as $\mathrm{R}=\Delta \mathrm{h} \times \mathrm{SY}$ where $\mathrm{R}$ is recharge, in $\mathrm{cm}$; $\Delta \mathrm{h}$ is change in water level rise, in $\mathrm{cm}$; and $\mathrm{SY}$ is specific yield (dimensionless).

\section{RESULTS AND DISCUSSION}

In this research, various factors such as detailed soil and land use maps, meteorological data, geologic data and water level fluctuation data were used which are important to characterize the groundwater recharge in the catchment. Based on the data an investigation was made to examine the effect of high-resolution meteorological data in groundwater recharge estimation in a semiarid climatic setting using the soil water balance and water level fluctuation methods. Both methods gave rise to similar results of groundwater recharge in the study area, which is significantly different from values of previous studies.

In the case of soil water balance method, the impact of combination of different soil types and land use/land cover on the actual groundwater recharge was studied by formulating matrix of parameters (Table 3). During the calculation of evapotranspiration, surface runoff and groundwater recharge, 16 combinations of soil and land use in selected two types of hydrological soil group classifications has been employed. As indicated in table 3, the water balance method resulted in average groundwater recharge and surface runoff values for each combination of soil type and land use/cover with an overall groundwater recharge and surface runoff of $89.04 \mathrm{~mm}$ and $38.59 \mathrm{~mm}$, respectively. The annual rates of groundwater recharge range between $7 \mathrm{~mm} / \mathrm{year}$ and $138.5 \mathrm{~mm} /$ year in the subsoil and soil/bedrock interface, which represent $2.25 \%-21.7 \%$ of the respective rainfalls. 
Table 3. Average groundwater recharges estimated using TMWB method.

\begin{tabular}{|c|c|c|c|c|c|c|c|}
\hline$A$ & $B$ & $C$ & $D$ & $E$ & $F$ & $G$ & $\boldsymbol{H}$ \\
\hline Land use & $\begin{array}{l}\text { Areal } \\
\text { coverage } \\
\left(\mathrm{m}^{2}\right)\end{array}$ & Proportion & $\begin{array}{l}\text { Soil Type } \\
\text { Coverage }\end{array}$ & $\begin{array}{l}\text { Proportion } \\
\text { Covered by } \\
\text { each soil }\end{array}$ & $\begin{array}{l}\text { Proportion } \\
\text { in soil type } \\
\left(E^{*} C\right)\end{array}$ & $\begin{array}{l}\text { Runoff } \\
(\mathrm{mm})\end{array}$ & $\begin{array}{l}\text { Recharge } \\
\text { (mm) }\end{array}$ \\
\hline \multirow[t]{5}{*}{ Farmland } & \multirow[t]{5}{*}{$52,345,628$} & \multirow[t]{5}{*}{0.553} & Sandy Loam & 0.09 & 0.05 & 1.34 & 4.83 \\
\hline & & & Silty Loam & 0 & 0 & 0 & 0 \\
\hline & & & Clay Loam & 0.52 & 0.29 & 11.86 & 25.55 \\
\hline & & & Clay & 0.39 & 0.22 & 9.01 & 26.23 \\
\hline & & & & & Sub-Total & 22.2 & 56.61 \\
\hline \multirow[t]{5}{*}{ Bare soil } & \multirow[t]{5}{*}{$29,636,163$} & \multirow[t]{5}{*}{0.313} & Sandy Loam & 0.16 & 0.05 & 1.41 & 5.08 \\
\hline & & & Silty Loam & 0.17 & 0.05 & 1.56 & 1.66 \\
\hline & & & Clay Loam & 0.49 & 0.15 & 6.34 & 10.66 \\
\hline & & & Clay & 0.18 & 0.06 & 2.27 & 5.75 \\
\hline & & & & & Sub-Total & 11.58 & 23.14 \\
\hline \multirow[t]{5}{*}{ Vegetation } & \multirow[t]{5}{*}{$6,401,306$} & \multirow[t]{5}{*}{0.068} & Sandy Loam & 0.09 & 0.006 & 0.17 & 0.62 \\
\hline & & & Silty Loam & 0.31 & 0.021 & 0.59 & 0.63 \\
\hline & & & Clay Loam & 0.31 & 0.021 & 0.87 & 1.46 \\
\hline & & & Clay & 0.29 & 0.02 & 0.82 & 2.08 \\
\hline & & & & & Sub-Total & 2.45 & 4.78 \\
\hline \multirow[t]{5}{*}{ Farmstead } & \multirow[t]{5}{*}{$5,770,569$} & \multirow[t]{5}{*}{0.061} & Sandy Loam & 0.1 & 0.006 & 0.18 & 0.64 \\
\hline & & & Silty Loam & 0.09 & 0.005 & 0.15 & 0.16 \\
\hline & & & Clay Loam & 0.68 & 0.041 & 1.7 & 2.86 \\
\hline & & & Clay & 0.13 & 0.008 & 0.33 & 0.85 \\
\hline & & & & & Sub-Total & 2.37 & 4.51 \\
\hline Total & $94,153,666$ & 0.996 & & & & 38.59 & 89.04 \\
\hline
\end{tabular}

Table 4. Groundwater recharge estimation based on groundwater level fluctuation.

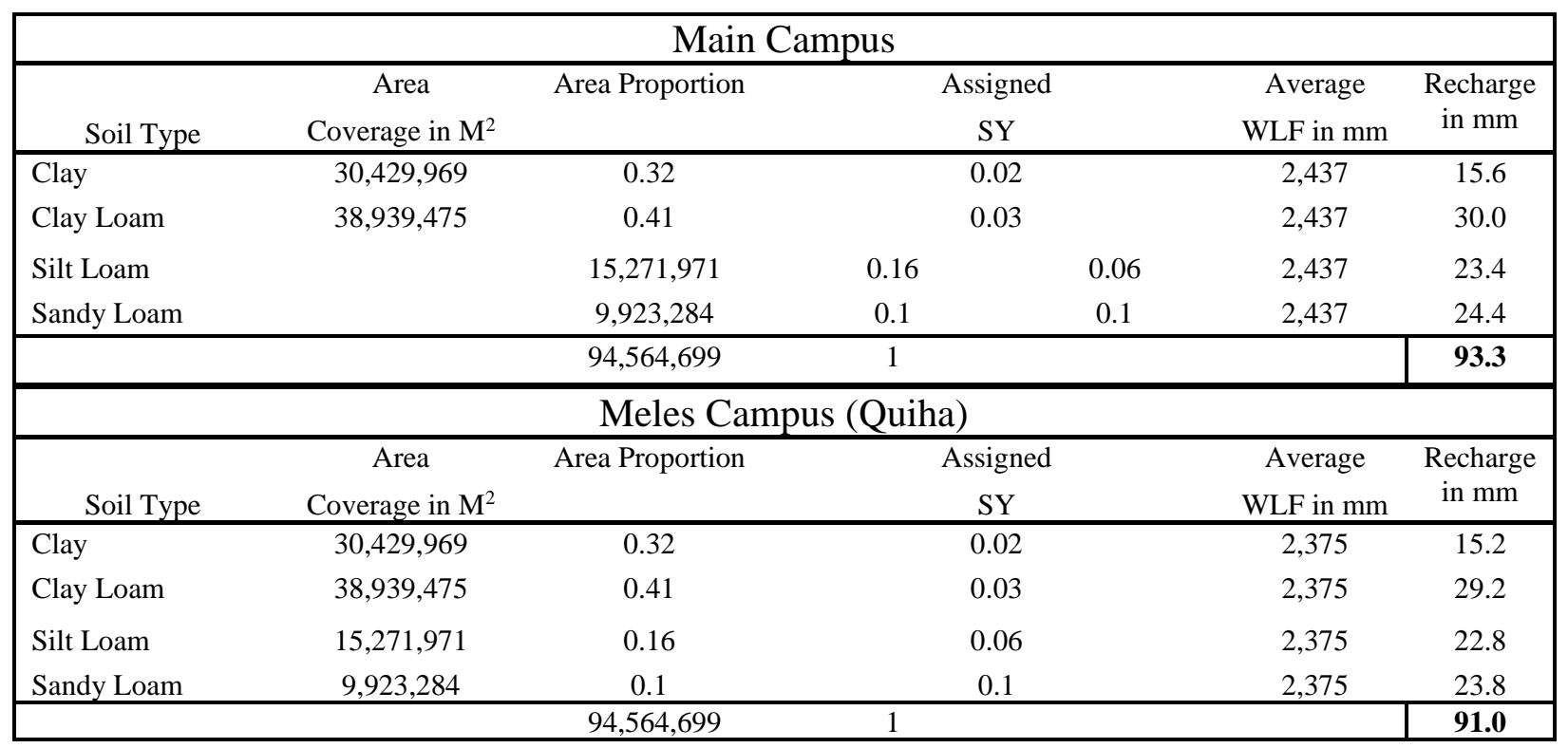




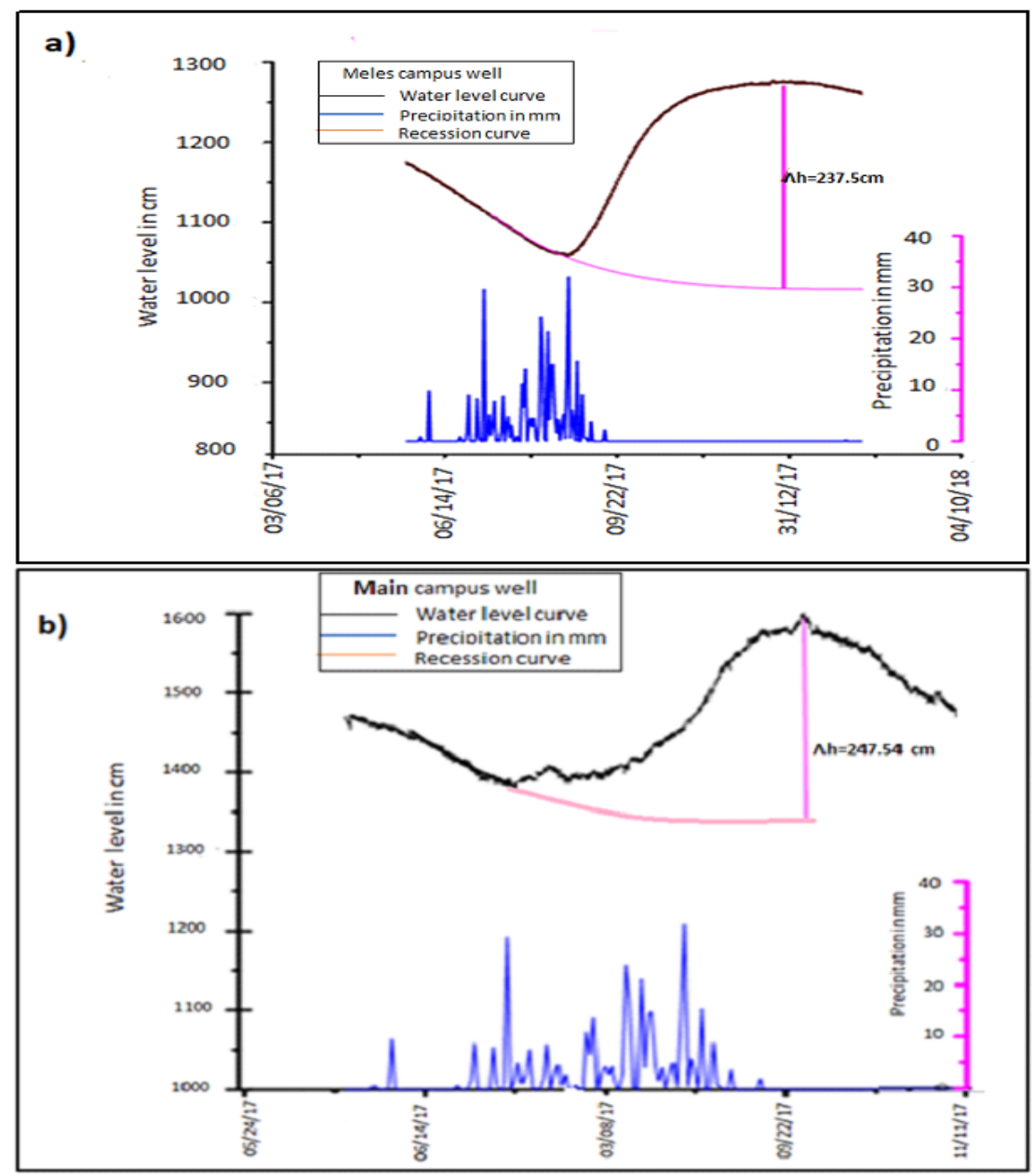

Figure 6. a) Water-table fluctuation in well at Meles Campus (Quiha); b) Water table fluctuation in well at Main Campus.

In water table fluctuation figure 6 ( $\mathrm{a}$ and $\mathrm{b}$ ) both wells show a delayed response to the rainfall which shows that significant time is needed for the infiltrated water to reach to the water table. This delay could be due to low percolation rate in the subsurface as a result of impervious layers in between the surface soils and the aquifer as well as the location of the well with respect to the recharge area. Hence, the short delay of response of the groundwater to rainfall in the well at Main campus and the relatively longer delay at the well in Meles campus is justified by the fact that the wells tap a semi confined aquifer that differ in the degree of weathering and fracturing of rocks as well the thickness of the confining layer. 
Comparison of the groundwater recharge values obtained from the Soil water balance method and WTF method are found to be similar suggesting that high resolution input data (meteorological, water table fluctuation, geological, soil, and land use/cover data) gives reliable result. On other hand, the groundwater recharge values obtained from previous studies range from 36 to $66 \mathrm{~mm} /$ year, which is small, compared to the present results. This discrepancy shows that previous studies have been underestimating the groundwater recharge in the catchment.

\section{CONCLUSION AND RECOMMENDATION}

The present study investigated the groundwater recharge of Aynalem catchment using soil water balance and water level fluctuation methods. In the present study a combination of different soil, land use parameters were used which gives different recharge amounts in different parts of the basin. These values were congregated by considering their proportion to come up with weighted value of the catchment. The obtained result of annual recharge is higher than results of previous studies in the catchment, which were analyzed based on monthly or yearly average meteorological data and less detail soil, land/used cover maps. Since the present study is based on more detailed data and applied two different methods, we can conclude that the recharge amounts reported in the previous studies where an underestimation of the real value.

Form this study; it can be concluded that the water balance approach coupled with water level fluctuation gives better result. It can also be concluded that groundwater recharge to deep wells in the catchment could be delayed for some time, for up to three months, depending on the type of surface soils, degree of weathering and fracturing of rocks, as well as the thickness of the confining layer. The study recommends that the groundwater monitoring effort should be continued by involving more sites in the catchment. It is also suggested that the land use/land cover changes should be updated as the catchment is in a dynamic state of change due to industrialization and urbanization.

\section{ACKNOWLEDGEMENTS}

Authors would like to take this opportunity to thank Mekelle University for the facilities provided to run this research work. We are also very grateful for MU-IUC VLIR-UOS hydrogeology project 
for funding this research. The Ethiopian Meteorological Agency, Mekelle branch, is also duly acknowledged for providing the data required for this research.

\section{CONFLICT OF INTERESTS}

No conflict of Interests.

\section{REFERENCE}

Allen, R.G., Pereira, L.S., Raes, D \& Smith, M. 1998. Crop evapotranspiration-Guidelines for computing crop water requirements. FAO Irrigation and drainage paper 56, 300p.

Arkin, Y., Beyth, M., Dow, D.B., Levitte, D., Haile, T \& Hailu, T. 1971. Geological map of Mekelle Sheet Area ND 37-11 Tigre Province. Geological Survey of Ethiopia, Map 1:25,000, ETH, Number 0037-0011.

Avery, W. H., Donovan, J. J \& Ketchum, J. N. 1999. Recharge Estimation by Stage-Discharge Interpolation of Spring flows from Cross-Correlated Well Measurements. Ground Water, 37(3): 332-337 (doi:10.1111/j.1745-6584.1999.tb01108.x).

Christian Leduc, G. F., Christelle, M \& Martial, D. 2000. Comparison of recharge estimates for the two largest aquifers in Niger, based on hydrodynamic and isotopic data. In TraM' 2000 Conference Tracers and Modelling in Hydrogeology, held at Liège, Belgium, IAHS Publ. no. 262: 391-399.

Fetter, C.W. 2001. Applied Hydrogeology. Upper Saddle River, New Jersey 07458.

Gebrehawaria, G. 2009. Groundwater resource assessment of Aynalem wellfield through transient flow modelling, Mekele, Ethiopia. MSc Thesis, Enshede. ITC.

Gebru, T. A \& Tesfahunegn, G. B. 2018. Chloride mass balance for estimation of groundwater recharge in a semi-arid catchment of northern Ethiopia. Hydrogeology Journal. 16p (DOI: 10.1007/s10040-018-1845-8).

Grismer, M. E., Bachman, S \& Powers, T. 2000. A comparison of groundwater recharge estimation methods in a semi-arid, coastal avocado and citrus orchard (Ventura County, California). Hydrological Processes, 14(14): 2527-2543 (doi:10.1002/10991085(20001015)14:14<2527::aid-hyp112>3.0.co;2-t). 
Hailu, G. 2008. Groundwater resource assessment through distributed steady-state flow modeling, Aynalem well field, Mekele, Ethiopia. MSc Thesis, Enschede, The Netherlands, ITC.

Hendrickx, J. A. 1997. Recharge from Precipitation. In: I. Simmers (Ed.), Recharge of Phreatic Aquifers in (Semi)-Arid Areas, IAH Contributions to Hydrogeology Series (Chapter 2). Rotterdam, Taylor and Francis, Balkema.

Hussien, A. 2000. Hydrogeology of the Aynalem wellfield, Tigray, Northern Ethiopia. MSc Thesis, Addis Ababa University, Addis Ababa (unpubl).

Johnson, A. I. 1967. Compilation of Specific Yields for Various Materials. Hydrological Properties of Earth Materials, Geological Survey Water-Supply Paper, 1662-D.

Kibrewossen Tesfagiorgis, T. G. 2011. Evaluation of the groundwater resources in the Geba basin, Ethiopia. Bulletin of Engineering Geology and the Environment, 70: 461-466.

Kinzelbach W, A. W.H. 2002. A Survey of Methods for Groundwater Recharge in Arid and SemiArid Regions. Early Warning and Assessment Report Series. Nairobi, ISBN 92-8070213180702133: UNEP/DEWA/RS.02-2, United Nations Environment Programme.

Lerner, D.N., Issar, A. S \& Simmers, I. 1990. Groundwater Recharge. A Guide to Understanding and Estimating Natural Recharge. In: International Contributions to Hydrogeology, V. 8, ISBN 3-922705-91-X, 345p (https://doi.org/10.2134/jeq1992.00472425002100030036x)

Marcelo, V., Rocío, C., Pablo, W \& Sebastián, D. 2013. Application of the water table fluctuation method to characterize groundwater recharge in the Pampa plain, Argentina. Hydrological Sciences Journal, 58(7): 1445-1455 (DOI:10.1080/02626667.2013.833663).

Maréchal, J. C., Dewandel, B., Ahmed, S., Galeazzi, L \& Zaidi, F. K. 2006. Combined estimation of specific yield and natural recharge in a semi-arid groundwater basin with irrigated $\begin{array}{llll}\text { agriculture. Journal } & \text { 329(1-2): }\end{array}$ (doi:10.1016/j.jhydrol.2006.02.022).

McCabe, G.J \& Markstrom, S.L. 2007. A monthly water-balance model driven by a graphical user interface: U.S. Geological Survey Open-File report 2007-1088, 6 p.

Misstear, V. P. 2006. Estimating groundwater recharge through tills: A sensitivity analysis of soil moisture budgets and till properties in Ireland. Hydrogeology Journal, 14(4): 548-561. 
Nimmo, J. R., Horowitz, C \& Mitchell, L. 2015. Discrete-Storm Water-Table Fluctuation Method to Estimate Episodic Recharge. Groundwater, 53(2): 282-292 (doi:10.1111/gwat.12177).

Rasmussen, W.C \& Andreasen, G.E. 1959. Hydrolgic budget of the Beaverdam Creek Basin. $U$. S. Geological Survev Water Supply Paper, 1472: 106 p (https://doi.org/10.3133/wsp1472).

Ratliff, L.F., Ritchie, J.T \& Cassel, D.K. 1983. Field-Measured Limits of Soil Water Availability as Related to Laboratory-Measured Properties. Soil Science Society of America Journal, 47(4): 770-775 (doi.org/10.2136/sssaj1983.03615995004700040032x).

Ritter, M.E. 2006. The physical environment: An introduction to Physical Geography. Available online at http://www.uwsp.edu/geo/faculty/ritter/geog101/textbook/title_page.html.

Samuel H. 2017. Groundwater recharge estimation using water balance and chloride mass balance methods in Aynalem wellfield. MSc. thesis. Mekelle University, Tigray, Ethiopia (unpubl.).

Saxton, K.E., Rawls, W.J., Romberger, J.S \& Papendick, R.I. 1986. Estimating generalized soilwater characteristics from texture. Soil Sci. Soc. Amer. J. 50(4): 1031-1036 (https://doi.org/10.2136/sssaj1986.03615995005000040039x).

Scanlon, B.R., Healy, R.W \& Cook, P.G. 2002. Choosing appropriate techniques for quantifying groundwater recharge. Hydrogeology J., 10: 18-39 (https://doi.org/10.1007/s10040-001-0176-2).

Scanlon, B.R., Keese, K.E., Flint, A.L., Flint, L.E., Gaye, C.B., Edmunds, W.M \& Simmers, I. 2006. Global synthesis of groundwater recharge in semi-arid and arid regions. Special Issue: Emerging Issues in Rangeland Ecohydrology, Hydrological Process, 20(15): 33353370 (https://doi.org/10.1002/hyp.6335).

SDG (Sustainable Development Goals). 2015. UNDP SDG report. 24p.

Sharda, V.N., Kurothe, R.S., Sena, D.R., Pande, V.C \& Tiwari, S.P. 2006. Estimation of groundwater recharge from water storage structures in a semi-arid climate of India. Journal of Hydrology, 329 (1-2): 224-243 (https://doi.org/10.1016/j.jhydrol.2006.02.015).

Sophocleous, M.A. 1991. Combining the soil water balance and water-level fluctuation methods to estimate natural groundwater recharge: Practical aspects. Journal of Hydrology, 124(34): 229-241 (https://doi.org/10.1016/0022-1694(91)90016-B). 
Tesfamichael G., De Smedt F., Miruts H., Solomon G., Kassa A., Kurkura K., Abdulwassie H., Bauer H., Nyssen J., Moeyersons J., Deckers J., Mitiku H \& Nurhussen T. 2010. Largescale geological mapping of the Geba basin, northern Ethiopia. Tigray Livelihood Paper No 9, VLIR - Mekelle University IUC Program, 46 p. ISBN 978-90-8826-134-3

Tesfamichael Gebreyohannes, Florimond De Smedt, Kristine Walraevens, Solomon Gebresilassie, Abdelwasie Hussien, Miruts Hagos, Kasa Amare, Jozef Deckers, Kindeya Gebrehiwot. 2013. Application of a spatially distributed water balance model for assessing surface water and groundwater resources in the Geba basin, Tigray, Ethiopia. Journal of Hydrology, 499: 110-123 (https://doi.org/10.1016/j.jhydrol.2013.06.026).

USDA. 1972. Design Hydrographs. Hydrology Part 630, National Engineering Handbook, Chapter 21, United States Department of Agriculture (USDA), Natural Resources Conservation Service (NRCS), Washington, 26p.

Vanum, G and Gebrerufael, H. 2012. Identification of groundwater type and recharge estimation through hydrochemical analyis: A case study in ayanalem well field, Northern Ethiopia. International Journal of Physical and Social Sciences Volume, 2(9): 578-595.

Xiuyu Liang \& You-Kuan Zhang, 2012. A new analytical method for groundwater recharge and discharge estimation. Journal of Hydrology, 450-451: 17-24 (https://doi.org/10.1016/j.jhydrol.2012.05.036).

Yehdego, S. 2003. Hydrogeology of Ilala-Aynalem catchments with particular reference to the chemical variation and aquifer characterization, MSc. thesis. Addis Ababa University, Addis Ababa (unpubl.).

Yoshihide Wada, Ludovicus P. H. van Beek, Cheryl M. van Kempen, Josef W. T. M. Reckman, Slavek Vasak, Marc F. P. Bierkens. 2010. Global depletion of groundwater resources. Geophysical Research Letters, 37(20): 1-5 (doi:10.1029/2010GL044571).

Zereay, T. 2007. Evaluating the potential of the Aynalem wellfield for the conjunctive use of surface and groundwater. MSc Thesis, Mekelle University, Mekelle, Ethiopia, 113p.

Zhang, L., Dawes, W.R \& Walker, G. R. 2001. Response of mean annual evapotranspiration to vegetation changes at catchment scale. Water Resources Research, 37(3): 701-708 (doi.org/10.1029/2000WR900325). 
Annexure I. Curve number $(\mathrm{CN})$ values for the combined hydrological soil groups for average antecedent soil moisture (Class AMC II).

\begin{tabular}{|c|c|c|c|c|c|c|}
\hline \multirow{2}{*}{$\begin{array}{l}\text { Land Use } \\
\text { Descrition }\end{array}$} & \multirow{2}{*}{ Treatment } & \multirow{2}{*}{$\begin{array}{l}\text { Hydrologic } \\
\text { condition }\end{array}$} & \multicolumn{4}{|c|}{ Hydrologic Soil Group } \\
\hline & & & $\mathrm{A}$ & B & $\mathrm{C}$ & $\mathrm{D}$ \\
\hline Fa11or & Straight rom & - & 77 & 86 & 91 & 94 \\
\hline \multirow{6}{*}{ Rot crop } & Straight. rom & Poor & 72 & 81 & 88 & 91 \\
\hline & \begin{tabular}{|l|} 
Straight rom \\
\end{tabular} & Good & 67 & 78 & 85 & 89 \\
\hline & Contoured & Poor & 70 & 79 & 84 & 88 \\
\hline & Contoured & Good & 65 & 75 & 82 & 86 \\
\hline & Cont. $\alpha$ terraced & Poor & 66 & 74 & 80 & 82 \\
\hline & Cont. $\alpha$ terraced & Good & 62 & 71 & 78 & 81 \\
\hline \multirow{6}{*}{ Sma 11 grains } & Straight ror & Poor & 65 & 76 & 84 & 88 \\
\hline & Straight rom & Good & 63 & 75 & 83 & 87 \\
\hline & Contoured & Poor & 63 & 74 & 82 & 85 \\
\hline & Contoured & Good & 61 & 73 & 81 & 84 \\
\hline & Cont. $d$ terraced & Poor & 61 & 72 & 83 & 82 \\
\hline & Cont. $\alpha$ terraced & Good & 59 & 70 & 78 & 81 \\
\hline \multirow{6}{*}{$\begin{array}{l}\text { Close-seeded } \\
\text { Legumes or rotation } \\
\text { meador }\end{array}$} & Straight row & Poor & 66 & 77 & 85 & 89 \\
\hline & Straight rom & Good & 58 & 72 & 81 & 85 \\
\hline & Contoured & Poor & 64 & 75 & 83 & 85 \\
\hline & $\begin{array}{l}\text { Contoured } \\
\end{array}$ & Good & 55 & 69 & 78 & 81 \\
\hline & Cont. $d$ tertraced & Poor & 63 & 73 & 80 & 83 \\
\hline & Cont. $\&$ terraced & Good & 51 & 67 & 76 & 80 \\
\hline \multirow{6}{*}{ Pasture or range } & & Poor & 68 & 79 & 86 & 89 \\
\hline & & Fair & 49 & 69 & 79 & 84 \\
\hline & & Good & 39 & 61 & 74 & 80 \\
\hline & Contoured & Poor & 47 & $6 ?$ & 81 & 88 \\
\hline & Contoured & Fair & 25 & 59 & 75 & 83 \\
\hline & Contoured & Good & 26 & 35 & 70 & 79 \\
\hline Meador & & Good & 30 & 58 & 71 & 78 \\
\hline \multirow{3}{*}{ Woods } & & Poor & 45 & 66 & 77 & 83 \\
\hline & & Fair & 36 & 60 & 73 & 79 \\
\hline & & Good & 25 & 55 & 70 & 73 \\
\hline Porests & & - & 56 & 75 & 86 & 91 \\
\hline Farmsteads & & - & 59 & 74 & 82 & 86 \\
\hline \multirow{2}{*}{$\begin{array}{l}\text { Roads (dirt) } \\
\text { (hard surface) }\end{array}$} & & - & 72 & 82 & 87 & 89 \\
\hline & & & 74 & 84 & 90 & 92 \\
\hline \multirow{2}{*}{$\begin{array}{l}\text { Comernerial } \\
d \text { business Area }\end{array}$} & & - & 89 & 92 & 94 & 95 \\
\hline & & - & 81 & 88 & 91 & 93 \\
\hline Industrial Area & & - & 77 & 85 & 90 & 92 \\
\hline Residenta1 Area & & - & 57 & 71 & 86 & 86 \\
\hline
\end{tabular}


Annexure II. Calculating recharge and runoff using Thornthwaite and Mather Water Balance (TMWB) model programmed in an excel sheet.

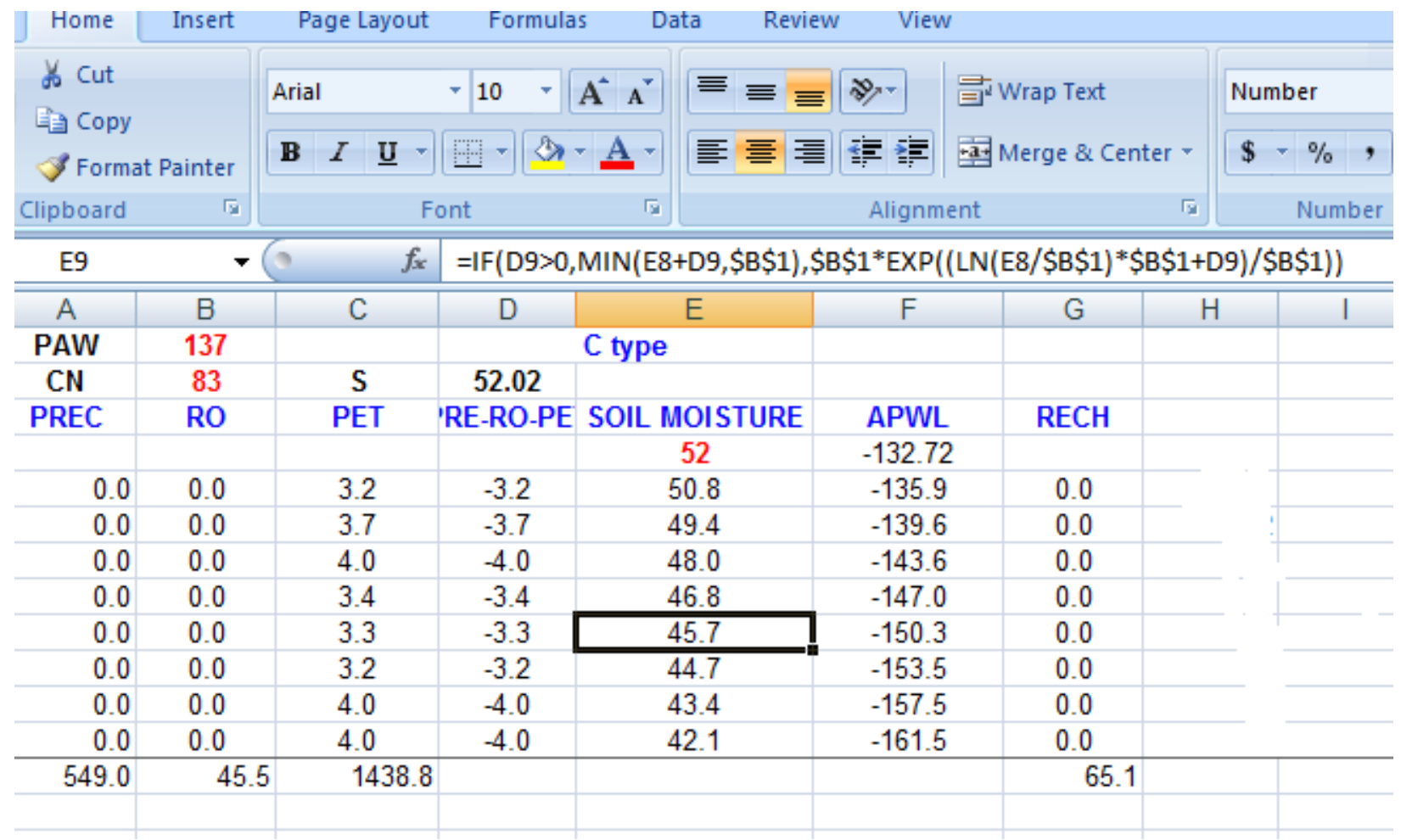

